\title{
Die GKSA se 'sendingstilstand' na 150 jaar
}

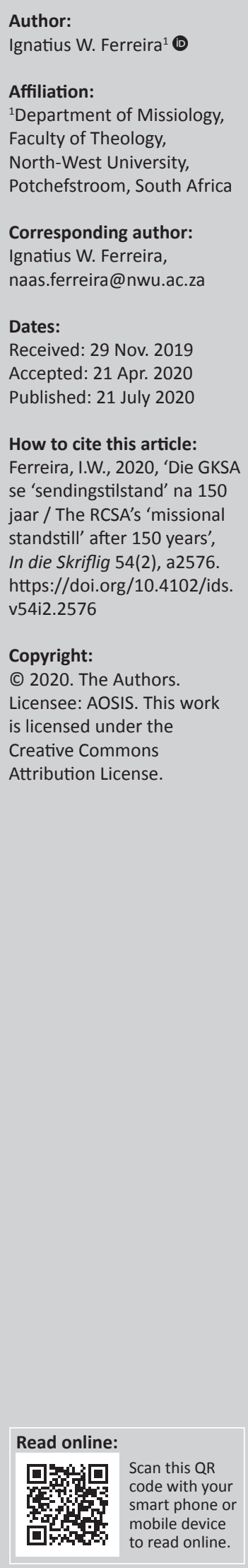

The RCSA's 'missional standstill' after 150 years: While the Reformed Churches in South Africa (hereafter RCSA) is looking back gratefully over the past 150 years, it is also compelled to reflect on its disparaging existence of the past 25 years. Several RCSA Synods have for some time, been paying close attention to comprehensive deputy reports on 'falling membership numbers'. They also have made incisive decisions on, among other things, a 'Conversion Strategy', and recently on a 'Church Growth Ministry'. The same reduction in numbers that degraded the Christian church within the Western culture to a post-Christendom reality, has also been identified in the RCSA. This article looks back in history and focuses, among other things, on the spiritual legacy of the RCSA. This legacy, from the historical and theological development of post-Reformational theology, and also from the Netherlands, influenced the church life of the RCSA in Southern Africa. This reflection is essential to really understand the current challenges of the RCSA in order to refocus its future biblical response to God's call. It is clear that the RCSA will have to reform missiologically in order to face the new postChristendom reality of our globalising world.

Keywords: GKSA sending; Post-Reformasie; Missionale kerkwees; Sendingfokus; Gereformeerde sending; RCSA mission; Post-Reformation; Missional church; Mission focus; Reformed mission.

\section{Inleiding}

Ongeveer 2000 jaar gelede het Jesus Christus die werklikheid van die koms van 'n nuwe koninkryk bekendgemaak (Matt 28:18). Hy gee by hierdie geleentheid aan sy kerk 'n baie duidelike opdrag (Matt 28:19-20); Hy gee ook 'n troosryke belofte van sy volgehoue teenwoordigheid in hulle midde (Matt 28:20), en Hy belowe ook om hulle deur die Heilige Gees vir hulle roeping toe te rus en te bemagtig (Hand 1:8; 2:4). So word die gestuurde kerk geroep en doelmatig toegerus om in die 'laaste dae' (Hand 2:7), ter wille van hierdie nuwe koninkryk, sy getuies in die hele wêreld te wees. Wanneer die getuienis van die evangelie van hierdie koninkryk al die nasies van die wêreld bereik het, sal die einde kom (Matt 24:13). Dit moet baie duidelik wees dat daar'n onlosmaaklike band tussen die vestiging van Jesus Christus se koninkryk, en die kerklike bekendmaking daarvan tot die einde van die wêreld en die einde van die tyd is. Vir hierdie doel word die kerk deur die Heilige Gees toegerus. Die verwagting is daarom dat die Christelike kerk met 'n geesgedronge dringendheid (Op 22:20) sal besig wees om sy opdrag gehoorsaam uit te voer.

Die opdrag waarmee Jesus Christus sy kerk op aarde met sy hemelvaart agterlaat, is baie duidelik. Ten spyte van hierdie duidelike opdrag is Floor (1990:99) van mening dat die Gereformeerde Kerke in Suid-Afrika (hierna GKSA) weinig bewus is van hierdie roeping. 'n Deputateverslag aan die Nasionale Sinode van die Gereformeerde Kerke in Suid-Afrika (1997) verklaar baie duidelik dat die Gereformeerde Kerke ‘nog nooit juis evangeliserende kerke was nie' (GKSA 1997:875). Die koninkryk van God is wel 'n sentrale bybelse motief in die gereformeerde teologie, maar volgens Vorster (1996:23), neem dit ongelukkig nie 'n sentrale plek in dieselfde tradisie in nie. Dit word selfs nie in die gereformeerde belydenisse omvattend bespreek nie (Floor 1981:6). Godschalk (1968:12) is van mening dat al die uitgebreide historiese besinning oor die betekenis van die koninkryk, nie regtig iets bygedra het tot ' $n$ dieper verstaan of selfs 'n beter konkretisering van die saak nie.

Die GKSA het gevolglik nie 'n bewussyn van of 'n fokus op haar missionêre roeping in hierdie wêreld nie. Die vraag kan ook gevra word of dit enigsins 'n deel van die GKSA se na-Reformatoriese erfenis was. Dit wil voorkom asof dit feitelik aanvaar kan word, volgens Kruger (1990:198), dat die kerke se visie in so 'n mate vernou het dat hulle inderdaad net teen die eie plaaslike gemeente se omheining vaskyk. Godschalk (1968:12) is van mening dat die uitgebreide fokus op die leerstuk 
rakende die kerk, veral in die tyd van die Reformasie, die fokus op die werklikheid van die koninkryk weggeneem het. Dit is volgens Verkuyl (1993:72) die rede waarom Jesus Christus in die loop van die geskiedenis selfs sonder sy koninkryk verkondig word. Spoelstra (1986) vra die belangrike vraag of ons gereformeerde kerk-wees nie dalk in strukture gestol het nie. Hierdie vraag moet baie ernstig opgeneem word.

Met die aanbreek van die 150-jarige feesvierings van die GKSA, moet bogenoemde in gedagte gehou word wanneer die Gereformeerde Kerke dringend oor die oorsake van hierdie missiologiese leemte besin. Die afgelope 25 jaar het verskeie GKSA-Sinodes aandag gegee aan omvattende deputaterapporte oor 'Dalende lidmaatgetalle' (GKSA 1997:871-882); indringende besluite is geneem oor ' $\mathrm{n}$ 'Omkeerstrategie' (GKSA 2015:491-529) en onlangs is verdere besluite oor ' $n$ 'Kerkgroei-bediening' geneem (GKSA 2018:1018-1101). Voordat die volgende 150 jaar gehoorsaam aangepak kan word, moet daar duidelikheid kom oor waar die GKSA haarself ten opsigte van die sendingopdrag bevind. Sonder die missionêre roeping is nie net die wese van die kerk in gedrang nie, maar is haar toekoms ook in die weegskaal.

Hierdie artikel neem die bybelse openbaring met betrekking tot die koms en vestiging van die koninkryk van God en die kerk se sendingopdrag in die lig daarvan, as vertrekpunt. Vanuit hierdie vertrekpunt word die oorsake van die kerklike 'sendingstilstand' binne die GKSA histories en teologies ondersoek. Die doel is nie om 'n volledige na-Reformatoriese sendinggeskiedenis weer te gee, of om die sendinggeskiedenis van al die reformatoriese kerke in Suider-Afrika te ondersoek nie. In hierdie artikel word slegs gefokus op sake wat relevant is vir die verstaan van die GKSA se sendingfokus, ter wille van dringende reformasie daaraan.

\section{Die 'koninkryk' as vertrekpunt}

Kerkvernuwing is teenswoordig een van die belangrikste temas in die moderne ekklesiologie en enigeen wat oor kerkvernuwing wil skryf, moet by die koninkryk begin (Vorster 1996:29). Ook Spoelstra (1986:16) het dit al vroeër waarskynlik geag dat die kerkvraag as struktuurvraag in die twintigste eeu, deur die koninkryksvraag teruggedwing moet word.

Volgens Snyman (1977:140) gaan dit in die Skrif om die openbaring van God en in die Godsopenbaring gaan dit om die koninkryk van God. Godschalk (1968:61) vertolk dit soos volg: 'Het heeft de alleenwijse God behaagd de geschiedenis van de mens te zetten in het teken van koningschap en Koninkrijk.' $\mathrm{Al}$ kom die gedagte of die begrip koninkryk van God as sodanig nêrens in die Ou Testament voor nie, loop dit tog soos 'n goue draad van Genesis tot Maleagi (Helberg 1980:4). Soos Vriezen (1977:498) dit stel: 'De heilsopenbaring Gods in de geschiedenis was het uitgangspunt van het geloof der oudtestamentische Godsgemeenschap, de vernieuwing dezer gehele aarde tot Koninkrijk Gods werd haar eindverwachting.'

Die Nuwe Testament open met die begrippe koninkryk en evangelie sonder om die betekenis van hierdie begrippe breedvoerig te verduidelik. Die rede hiervoor is dat die betekenis van beide hierdie begrippe in hulle Ou-Testamentiese agtergrond gevind moet word. Die betekenis van beide begrippe word dus veronderstel (Coetzee s.a.:13; Floor 1981:9). Die hele Nuwe Testament laat die saak van die koninkryk van God stelselmatig ontvou. Dit word sigbaar in die aankondiging van die koms van die koninkryk in die Evangelies, die uitbreiding van die koninkryk in die boek Handelinge, die ontvouing van die koninkryk in die Nuwe-Testamentiese briewe en die voltooiing van die koninkryk in die boek Openbaring. ${ }^{1}$

Veral wanneer die koninkryk en die kerk met mekaar in verband gebring word, is die eeue-oue worsteling nog steeds om die bybelse ewewig tussen die twee uiterstes te vind: uiterstes naamlik van die volledige identifikasie van koninkryk en kerk (soos by die Roomse Kerk) en die volledige differensiasie van koninkryk en kerk (soos by die Montaniste). Volgens Kooiman (in die voorwoord van Lindijer 1962:vii) word 'n groot deel van die geskiedenis van die Christendom beheers deur die 'controverse' tussen die dinamiek van die Ryksgedagte en die statiese element wat aan kerkwees verbonde is.

\section{Die historiese ontwikkeling van die Gereformeerde Kerke se sendingfokus Die Reformasie en die sending}

Gedurende die tyd van die Reformasie is die waarhede van God se Woord met betrekking tot die wese van die kerk van Jesus Christus, na 'n lang tyd van kerklike verval, weer herontdek. Die verwagting is sekerlik dat die saak van die wese en belang van die sending van God se kerk ook duidelik in die tyd van die Reformasie na vore sou tree. Daar blyk egter 'n groot mate van onduidelikheid en onsekerheid hieroor te wees.

By sommige leiers van die Reformasie was daar skynbaar 'n openlike negatiwiteit oor die sending. Hulle was van mening dat die oorspronklike apostels die werk klaar afgehandel het, en dat die kerk van latere eeue nie die gesag of die verantwoordelikheid het om sendelinge uit te stuur nie (Kane 1978:73). Ook Gustav Warneck (aangehaal deur Bosch 1991:244) sluit hierby aan: 'Fundamental theological views hindered them from giving their activity and even their thoughts, a missionary direction.' Terwyl die Roomse sending juis in die tyd van die Reformasie sterk opgeleef het, was die eeu van die Hervorming 'een zeer magere zendingeeuw' (Wiersinga 1959:33), en was die kerke van die Reformasie 'bijna werkeloos op zendingsgebied' (Van Andel 1912:10). Volgens Van den Berg (1956:4) is dit 'a much discussed, but as yet not fully solved riddle'. Daar is selfs nie eers sprake van 'n latente missionêre ywer nie, want die probleem lê onder die oppervlakte in die Reformatore se denke (Van den Berg 1956:5). Dit blyk dat die oorwig van literatuur dit onomwonde stel dat die Reformatore nie die blywende sendingtaak van die kerk goed raakgesien

1.Vir'n meer volledige bespreking hieroor, sien Ferreira $(2002: 14-32$; sien ook Ferreira 2004). 
het nie, en dat dit die rede is waarom die sending nie tot sy reg kom in die (gereformeerde) belydenisskrifte en kerkorde nie (Du Plessis 1960:30).

Begrip moet gevra word vir die feit dat die tydperk van die Reformasie histories ' $n$ baie moeilike en beproewende tyd was. Baie skrywers pleit vir begrip in hierdie verband. Kane (1978:74) som die situasie soos volg op: 'The Protestant Churches, preoccupied as they were with the problem of survival, may be excused for having neither the vision nor the vigor for world evangelization.' Die teologie het hom in hierdie tyd toenemend besig gehou met die kerk, veral met die verlede en met die korrekte leer (Bosch 1997:125). 'De taak was niet eers expansie, maar concentratie op de zuivere leer' (Augustiny 1963:134). Dit is ook 'n feit dat die Protestante, anders as die Roomse Kerk, tot in die sewentiende en agtiende eeu, min met heidene in aanraking was (Van der Walt s.a.:4). Ook De Klerk (1923:27) spreeksy teleurstelling uitoor diegebrek aan sendingbeginsels, maar wys tog ook op die feit dat die Reformatore geen tyd (as gevolg van die omvattende taak van die Reformasie), asook geen geleentheid (as gevolg van geen oorsese besittings) vir sending gehad het nie (De Klerk 1923:28).

Die afgelope 25 jaar het al hoe meer navorsing die lig gesien wat heeltemal ' $n$ ander perspektief op die Reformasie en veral op Calvyn en sy siening van sending werp. Hierdie navorsing maak dit duidelik dat 'various aspects of Calvin's doctrines not only imply missions, but that the reformer actually demonstrated ardent longing for the conversion of non-Christians' (Buys s.a.:2). James (2001) stel dit op grond van 'documented evidence all over Europe' dat gedurende die laaste 10 jaar van Calvyn se lewe (1554-1564), die 'overriding preoccupation of Calvins life, was Missions'. James praat ook van die 'misconceptions about Calvin and his beliefs' en hy noem Calvyn 'one of the greatest missionaries the world has ever known'. Volgens hom is dit verstommende feite wat nie algemeen bekend is nie.

Gustav Warneck (1902) word as die vader van die moderne Sendingwetenskap beskou. Hy het met sy klassieke werk, History of Protestant missions 'n beduidende invloed op die gereformeerde wêreld uitgeoefen. Sy invloed was sodanig dat sy negatiewe missionêre beoordeling van die tydperk van die Reformasie, sekerlik as agtergrond kan dien vir die oorwegend afwysende houding van die missionêre literatuur met betrekking tot die bydrae van die Reformasie. Na aanleiding van die resultate van meer resente navorsing, kan die volgende vraag ook gevra word: Is daar werklik 'n reformatoriese stilte oor die saak van die sending, of is dit eerder 'n reformatoriese onontdekking of onopsigtelikheid? Hopelik sal nuwe navorsing binnekort hierop 'n antwoord kan gee (Ferreira 2004).

\section{Na-Reformatoriese sendinggeskiedenis \\ Nederlande}

Hoewel daar geen groot Hervormer in die Nederlande opgetree het nie, het die invloed van die Reformasie baie sterk deurgewerk (Du Toit 1970:107). Tog was die prentjie veral in die suide nie rooskleurig nie. Die Roomse Kerk wat gedurende hierdie tyd tot nuwe lewe ontwaak het (Grosheide et al. s.a.:331), het met al die staatsmag tot hulle beskikking die Protestante met die swaard vervolg. Die Nederlande het in 1523 die eerste martelare van die Reformasie opgelewer (Lindsay 1908:224). Die na-Reformatoriese kerkgeskiedenis in die Nederlande speel af teen die donker agtergrond van die Tagtigjarige Oorlog met Spanje (1568-1648). Onder hierdie moeilike omstandighede is wel belangrike kerklike vergaderings gehou wat aan die Gereformeerde Kerke vaste vorm gegee het (Du Toit 1970:109). Die lang oorlog teen Spanje het die geestelike energie van die kerke gestimuleer en spoedig het universiteite en teologiese skole van formaat ontstaan. Die nuutgevonde teologiese vryheid het egter ook 'n negatiewe nadraai gehad. Dit het aanleiding gegee tot die opkoms van teologiese verskille wat in baie ernstige dispute ontaard het. Die Sinode van Dordrecht (1618-1619) het vergader om hierdie teologiese twispunte te hanteer.

In 1602, met die samesmelting van verskillende handelsmaatskappye, is die Verenigde Oos-Indiese Kompanjie (V.O.C.) in Nederland tot stand gebring. Nederland het ook 'n seemoondheid geword. Hierdie maatskappy was bestem om 'n buitengewone invloed op die geskiedenis van Suid-Afrika uit te oefen (Jooste 1958:9). Die na-Dordtse tydvak val saam met die sogenaamde Goue Eeu van Nederland (Hamersma 1911:209) waartydens die handel van die Oos- en Wes-Indiese Kompanjie kosbare skatte na Nederland gebring het. Hierdie bloeitydperk kon vir die kerk in Nederland en die sending, in die besonder, veel voordeel ingehou het. Ongelukkig het juis die teenoorgestelde gebeur. Die tyd van materiële voorspoed het vir Nederland ' $n$ tyd van geestelike agteruitgang beteken. Hamersma (1911:217) noem hierdie tyd, wat tot in die agtiende eeu sou voortduur, 'die triomf van die ongeloof'. Daar was egter ook 'n ander probleem waarmee die kerk in Nederland geworstel het. Die noue verbintenis tussen kerk en staat het die kerk ook in alle opsigte lamgelê. Die kerk was nie heeltemal vry in sy bewegings nie en kon gevolglik ook nie enige sendingwerk selfstandig onderneem nie. Hy moes dit aan die staat, in hierdie geval die V.O.C., oorlaat om predikers uit te stuur. Die V.O.C. het die instrument geword waardeur die kerk haar begeerte om sending te bedryf, kon vervul (De Klerk 1923:40).

\section{Suid-Afrika}

Hamersma (1911) verduidelik die historiese verloop van sake:

Hoewel de Roomsen mensen, de Portugezen, het eerste bekend waren met dit puntje van de wereld, heeft God het toch zo beskikt, dat de Gereformeerde leer hier eerste vaste voet kreeg. Dit is een vingerwijzing Gods tot in verre geslachten. (p. 268)

Tydens hierdie eerste tydperk van die volksvestiging aan die Kaap het die oorheersing van die staat, asook die feit dat die kerk nog te veel van die klassis en die kerk van Amsterdam afhanklik was, veroorsaak dat die kerk aan die Kaap geen selfstandige sending ter hand geneem het nie (De Klerk 1923:49). Tydens die agtiende eeu het daar met die Aufklärung (tyd van Verligting) dramatiese veranderings in Europa 
plaasgevind wat ook die kerklike situasie in Suid-Afrika ingrypend sou verander. Jean Jacques Rousseau (Duignan \& Cranston 2020) se Vryheid, Gelykheid en Broederskap het 'n filantropiese en humanitêre gees in Europa wakkergemaak wat ook kerke en universiteite aangetas het. Met die ontdekking van die nuwe wêrelde het ' $n$ nuwe belangstelling in die sogenaamde natuurvolke ontstaan. Die Metodisme en Piëtisme, wat in reaksie teen die Ortodoksie na vore tree, het begin om veld te wen en sou die draers van 'n nuwe belangstelling in die sending word. Dit het aanleiding gegee tot die totstandkoming van Genootskaplike sending wat ongetwyfeld 'n blywende invloed op die sendingsituasie in Suid-Afrika uitgeoefen het. Hierdie genootskappe het nie net op 'n onkerklike wyse tot stand gekom nie, maar is ook op 'n onkerklike wyse bedryf. Van der Vyfer (1958:398) sien hulle negatiewe invloed as die wortels van 'n negatiwiteit, wat nie net deels verantwoordelik was vir die Groot Trek nie, maar ook sterk daartoe aanleiding gegee het dat daar 'n groeiende verset teen die sendingaksie as sodanig ontstaan het. De Klerk (1923:85) beweer dat die Hollandse Kerke in SuidAfrika nooit vyandig teen die sending as sodanig was nie, maar dat hulle wel 'n vooroordeel gehad het teen die manier wat sending bedryf is. Selfs ds. Dirk Postma het hierdie toedrag van sake as agtergrond gesien vir die felle teëstand wat hy van sommige lidmate teen die sending ervaar het (Van der Vyfer 1958:396-397).

Die tyd van die Groot Trek was inderdaad 'n tyd van groot kerklike worsteling. In hierdie worsteltyd het die GKSA ook tot stand gekom. Dit verdien vermeld te word dat ds. Dirk Postma, wat 'n belangrike rol gespeel het in die totstandkoming van die GKSA, na Suid-Afrika gekom het met 'n idealisme ten opsigte van sy sendingtaak, wat hoë vlugte geneem het. Nadat die Gereformeerde Kerk in 1859 gestig is, spreek dit volgens Du Plessis (1959:121) vanself dat die Gereformeerde Kerke vir eers nie veel kon doen om die sendingtaak te bevorder nie. Dirk Postma se aandag was so in beslag geneem deur die stigting van die Gereformeerde Kerk en die dinge wat daarna gebeur het, dat hy nie nog intensiewe aandag aan die sending ook kon gee nie (Van der Vyfer 1958:396). As gevolg van die geskiedenis van die Groot Trek was daar ook aan die beginjare 'n teenstand teen die sending by 'n groot groep lidmate (Du Plessis 1959:121). Die stormjare wat die Groot Trek voorafgegaan het, was nog vars in baie lidmate se geheue. Uiteindelik sou die Gereformeerde Kerke hulleself oor hierdie saak moes verantwoord. 'n Baie kort opsommende oorsig oor die besluite van GKSA-sinodes word weergegee. ${ }^{2}$

\section{Volgens die GKSA-sinodes}

Die sinodes van die Gereformeerde Kerke het spoedig oor die saak van die sending gehandel en het volgens De Klerk (1923:136), reeds vanaf die eerste Sinodes erns gemaak met die taak van die sending. Die eerste Sinode wat in 1869 in Potchefstroom gehou is, moes hom uitspreek oor die vraag of die bediening van die evangelie aan die nasies 2.Vir'n meer volledige oorsig, sien Ferreira $(2002: 73-87)$. en godsdienstige onderwys aan die huisbediendes 'n 'gelykstelling' sou wees (Jooste 1958:323). Die Gereformeerde Kerke moes hulleself verantwoord oor tendense wat reeds in die Kaapse Kerk praktyk geword het en wat as ' $n$ vrees by baie lidmate gelewe het. Die sendingprobleem het volgens Spoelstra (1963:240) die rasseprobleem geraak. Enigeen wat sinvol oor enige van hierdie twee sake sou wou navorsing doen, sal hierdie werklikheid in ag moet neem.

Die eerste jare van 1869 tot 1897 kan as die beginjare beskrywe word. In hierdie tyd moes die Gereformeerde Kerke deur vele beproewings gaan om hulleself as nuwe kerk binne die groter opset van Suid-Afrika te vestig. Sinodale besluite van hierdie tyd het van 'n sterk geloofsoortuiging en sendingbesef getuig, en het volgens Du Plessis (1959:123) verreikende en grondleggende betekenis gehad. Die ywer om sendingwerk te doen, was wel daar soos blyk uit 'n skrywe van president Paul Kruger wat by die Sinode van 1897 voorgelees is (Du Plessis 1959):

Daar het vanaf de stichting der Gereformeerde Kerk mijne begeerte geweest is dat de Geref. Kerk overeenkomstig hare roeping moch arbeiden tot de uitbreiding van Gods Koninkrijk en de kerk nog vroeger zwak was om alle zaken te kan behartigen, maar nu mijns insiens met die uitbreiding onzer kerk die roeping hare dure plicht vindt, vertrouw ik dat deze Synode tot een bepaalde werkzaamheid zal kunnen overgaan. (p. 124)

Paul Kruger het persoonlik 'n aansienlike bedrag geld in hierdie verband gegee. Net twee jaar later, in 1899, het die Tweede Vryheidsoorlog egter begin.

Gedurende die tweede tydperk, is die sending só gesentraliseer dat die plaaslike kerk in wese feitlik uitgeskakel is. Dit kan die tydperk van Sinodale sendingwerk genoem word (1904-1945). Die hoogtepunte gedurende hierdie tydperk was die werk wat vanuit die Gereformeerde Kerk Pretoria in Soutpansberg begin is, en die verskyning van $\mathrm{dr}$ P.J.S. de Klerk se proefskrif: 'Kerk en sending in Suid Afrika'. Vir Jooste (1958:344) is die hele tydperk tot en met 1945 gekenmerk deur die feit dat die ou beleid van die kerk, naamlik dat elke kerkraad binne sy eie omgewing geroepe is om sendingwerk te doen, nou minder beklemtoon word. Ook ds. H. du Plessis wat aan die Gereformeerde Kerke as 'n genootskap gedink het, wou vanaf 1936 die 'kerk as geheel' by die sending betrek (Spoelstra 1999:155).

Die derde tydperk was 'n tyd van groot politieke omwentelings. ${ }^{3}$ Die sendingfokus is weer teruggebring na die plaaslike kerk se werksaamhede in hulle eie omgewing. Gemeentes het die sendingveld in hulle eie omgewing begin raaksien. Die veelheid van plaaslike sendingaksies wat ontstaan het, het die behoefte aan opleiding van helpers, evangeliste en predikante ook ter sprake gebring. Sinode 1955 het besluit om iemand te benoem en ds. H. du Plessis is in dieselfde jaar deur die sendingdeputate van die Algemene Sinode daarvoor beroep.

3.Die is die tydperk van die Tweede Wêreldoorlog en die nagevolge daarvan. Groot demografiese veranderings het plaasgevind in die massale toestroming van nieblankes na die stede. Die sendingvelde wat ver was, het nou skielik naby gekom. 
Vanaf 1958 het die politieke toneel dramaties verander. Die onstellende openbaring deur die Tomlinson Kommissie en die Volkskongres van 1956 aangaande die baie groot agterstand van die sending van die Afrikaanse kerke, het volgens Du Plessis (1959:129) 'n onuitwisbare indruk op die Afrikaanse gelowige in die breë gemaak, en hulle is in die diepste van hulle gewete geraak. Die regering het die Tomlinson-verslag heeltemal geïgnoreer en die weg van rassediskriminasie op koloniale model voortgesit (Spoelstra 1999:192). Die invloed en gevolg wat dit vir die sending sou meebring, is nog nie verreken nie. 'n Latere Sinode (GKSA 1961:212) het wel die behoefte uitgespreek om die saak, in hoeverre staatsbeleid die sending benadeel, in studie te neem, maar hulle het ongelukkig nie verder daaraan aandag gegee nie. 'n Omvattende rapport wat by die Sinode van 1958 gedien het, het nie net gewys dat die GKSA deeglik bewus was van die geestelike nood in Afrika nie, maar ook dat die GKSA (1958:139-157) hulleself daadwerklik verbind het om ook iets daaraan te doen. Van hierdie voorneme kom daar egter nie veel in verdere sinodebesluite na vore nie. Die Sinode van 1961 (1961:211-212) het 'n rapport behandel waarin 'n duidelike beeld van die sendingtoestand binne die GKSA uiteengesit word. Verskeie rapporte van Sendingdeputate dien by opeenvolgende sinodes (1982-1988) wat onder andere ook die duidelike leemtes in die sending uitwys (GKSA 1988:362-373). Niks noemenswaardigs gebeur egter in 1991 en 1994 nie. 'n Beskrywingspunt waarin die behoefte uitgespreek word dat die GKSA'n baie hoë prioriteit aan evangelisering moet gee, dien by Sinode 1997. Aan hierdie beskrywingspunt word gevolg gegee. Tydens dieselfde Sinode word daar egter, sonder opgaaf van redes, nie weer Sendingdeputate benoem nie (GKSA 1997:379). 'n Studierapport oor die kommerwekkende daling in lidmaatgetalle binne die GKSA dien ook op hierdie Sinode. Hierdie rapport stel dit sonder ' $n$ omhaal van woorde dat van evangelisering daar nie veel in die Gereformeerde Kerke tereg kom nie. Die konklusie is duidelik: Die Gereformeerde Kerke was 'nog nooit juis evangeliserende kerke nie' (GKSA 1997:875). Die aangewese deputate insake die 'Bewaring en vermeerdering van die Kerk' (GKSA 1997:881-882) moes by Sinode 2000 die feit betreur dat slegs 67 kerkrade uit 'n steekproef van 300, en slegs 4 klassisse uit 'n steekproef van 30 op navraag van hierdie deputate gereageer het.

Dit wil voorkom asof enige gesamentlike sendingfokus van die GKSA as kerkverband, heeltemal ontbreek het. Kruger (1990:198) is van mening dat die Gereformeerde Kerke teen hulle eie mure vaskyk. Die sendingwerk wat wel plaasgevind het, het op ' $n$ 'paternalistiese wyse' plaasgevind (Spoelstra 1999:293) en het eerder daartoe gelei dat 'kultuuroordrag' bewerk is (Spoelstra 1999:294). Hierdie sending was tot 'n baie groot mate slegs maar die 'finansiële ondersteuning van jong kerke' (Spoelstra 1999:302-303). Dit moet eintlik as 'tjekboeksustentasie' van kerke in swart woongebiede beskryf word. Dit is die rede waarom Spoelstra (1999) uiteindelik die vraag moet vra of die sendinggeskiedenis van die GKSA (1869-1994) 'n sending vir die kerk, of 'n sending vir die koninkryk, sigbaar maak.
Die suksesse al dan nie van enige individuele pogings en projekte van plaaslike gemeentes is nie in die fokus van hierdie studie nie. Daar word gepoog om deur'n wyehoeklens die sendingwerk van die GKSA uit te beeld. Die skrywer wil ook hier duidelik maak dat hy nie die fokus geplaas het op die geskiedenis van die 'jonger kerke' ${ }^{4}$ wat nou deel vorm van die GKSA nie.

Die kontinent van Afrika het ná 1994 se politieke omwenteling in Suid-Afrika oopgegaan, en daar het wonderlike geleenthede vir die verkondiging van die evangelie ontstaan. Binne die historiese ontwikkeling van die Gereformeerde Kerke se sendingfokus, het die saak van die sending egter nooit werklik tot sy reg gekom nie. Binne hierdie perspektief wil dit werklik voorkom asof Vorster (1996:23) reg is wanneer hy beweer dat die GKSA op 'n verbypad beweeg - 'n pad heeltemal verby die samelewing en sy woelings.

\section{Die teologiese ontwikkeling van die Gereformeerde Kerke se sendingfokus}

\section{Na-reformatoriese teologiese ontwikkeling in Nederland}

Hoewel die kultuur-en geestesgeskiedenis van Wes-Europa na die Reformasie ' $n$ ingewikkelde legkaart van stromings en teëstromings is wat nie maklik oorgesien kan word nie (Schulze 1978:232), is dit tog moontlik om die breë hooflyne aan te dui en te verken. Tydens die oorgang van die sestiende na die sewentiende eeu, het nie net die bloedige Tagtigjarige Oorlog met Spanje 'n baie besliste merk op kerk en samelewing gelaat nie, maar 'n kerklike en teologiese stryd het ook in Europa gewoed. Dit was die tyd van die Remonstransie. Alhoewel die Sinode van Dordrecht as die hoogtepunt van die Reformasie beskou kan word, het die gees van die Arminianisme wat deur hierdie Sinode veroordeel is, tog bly voortlewe (Kruger 1957:18). Die gevolge van hierdie voortdurende stryd op kerklik-teologiese terrein, was die toenemende aksent wat op die intellektuele aspek van die geloof geplaas is. Daar is al meer en meer gefokus op die korrekte geloof soos uitgedruk in versigtig gedefinieerde logiese stellings (Hofmeyer soos aangehaal deur Kruger 1997:18). Hierdie tendens het daartoe aanleiding gegee dat die gevoelsmatige van die godsdiens op die agtergrond geskuif het en dat begin is om die menslike rede tot die beginsel van alle dinge te verhef. Hierdie tydperk word deur Schulze (1978:232) beskrywe as die sogenaamde Konfessionele tydperk waarin, teologies gesien, die aksent op die suiwerheid van die leer gelê is - vandaar ook die benaming Ortodoksie.

Dit was volgens Kruger (1997:18) die begin van die gereformeerde Skolastiek wat tot grootskaalse verstarring van die teologie gelei het. Dit het van die geloof niks anders nie as verstandelike instemming met 'n corpus van dogmatiese leerstellinge gemaak. Die kerklike fokus is slegs op teologiese 4.Jonger kerke is kerke wat uit sendingwerk ontstaan het. 
en dogmatiese suiwerheid gerig. Nie alleen is die lewe van die lidmate uit die oog verloor nie, maar ook is die politieke, leerstellige, kerkregtelike en liturgiese hervormings van die eerste geslag hervormers nie na die alledaagse lewe van die 'kerkvolk' deurgevoer nie (Stoeffler soos aangehaal deur Kruger 1997:18). Die uiteindelike gevolg is dat die nawerking van die Reformasie in dogmatiese leerstelligheid 'versteen' het. Hierdie verstandelike verstarring het aansluiting gevind by die algemene intellektuele opbloei van die Rasionalisme op Europese bodem.

In die tydperk ná die Sinode van Dordt het die Aufklärung en die gepaardgaande rasionalisme so 'n verlammende uitwerking op die kerk van die agtiende eeu gehad, dat weinig van die kerk se sendingroeping tereggekom het (Van der Vyfer 1958:397). Du Plessis (1960:36) is daarvan oortuig dat daar in die agtiende eeu geen verdere uitbouing van die reformatoriese sendingbeginsels op reformatoriese fondament plaasgevind het nie.

Nederland het in die begin van die sewentiende eeu 'n tydperk van groot welvaart en voorspoed binnegegaan. Dit word die sogenaamde 'Goue Eeu' van Nederland genoem. Die einde van die oorlog met Spanje, asook die groot rykdomme wat van die Ooste af ingekom het, het die waardes van die Nederlandse volk heeltemal verander. Daar was ongekende voorspoed op kulturele, ekonomiese en politieke gebied. Die Nederlandse gemeenskap van daardie tyd was hoofsaaklik materialisties, met alle klem op gemak en persoonlike sekuriteit (Kruger 1997:18-19). 'n Grootskaalse sedelike verval, kerklike formalisme en 'n gees van intellektualisme het as die heersende lewensgees begin opvlam. Vir Van 't Spijker (aangehaal deur Kruger 1997:19) is dit die duidelike bewys hoe oppervlakkig die Reformasie eintlik in die Nederlande deurgewerk het.

Hierdie nuwe materialistiese lewensgees het reaksie uitgelok. 'n Eensydige beklemtoning van 'n saak lok volgens Schulze (1978:237-238) baie dikwels 'n ewe eensydige reaksie na vore. Net so het ' $n$ alternatiewe lewensgees, in verset teen die materialisme en dekadensie van daardie tyd, onder sommige Protestante in Nederlandse kerke posgevat. Die koue en verstarde ortodoksie het aanleiding gegee tot die opkoms van die Piëtisme en die Metodisme. Hierdie beweging of alternatiewe gees word ook die sogenaamde Nadere Reformasie of gereformeerde Piëtisme genoem (Kruger 1997:21). Volgens Kruger (1997:23) is die Piëtisme hoofsaaklik 'n reaktiewe beweging wat, sonder om revolusionêr te wees, in verset was teen die heersende moraal in Engeland en Europa, veral binne die kringe van die Protestantse Ortodoksie. Hy stel dit duidelik dat die Gereformeerde Piëtisme nie sonder meer verwerp kan word as ' $n$ nie-reformatoriese beweging nie. Tot ' $n$ mate het dit die ideale van die Reformasie voortgedra in 'n nuwe eeu en onder nuwe omstandighede. Die Piëtisme en die Nadere Reformasie sou die saak van die sending, wat na die Reformasie van die sestiende eeu heeltemal agterweë gebly het, ter hand neem.
As gevolg van al die bogenoemde redes, was die Christelike sending teen die einde van die agtiende eeu in 'n treurige toestand (De Klerk 1923:68). Daar het weinig van die kerklike sendingroeping tereg gekom (Van der Vyfer 1958:397). Die sendingontwikkeling wat wel plaasgevind het, het nie vanuit die rasionalisme gekom nie, maar was piëtisties en later metodisties (Du Plessis 1960:38). Spoelstra (1999:286) stel dit soos volg: 'Die gereformeerde sending is aan die einde van die 18de eeu met Protestantisme as vader en Piëtisme as moeder op die bed van Europese "kolonialisme" gebore.' Die werklike sendingontwaking van hierdie tyd het saamgeval met die ontdekking van die onbekende wêreld buite Europa. Dit gaan volgens Spoelstra (1999:4) met 'n sogenaamde: 'scramble for Africa' gepaard. Dit was nie altyd uit gehoorsaamheid aan die bevel van Christus gebore nie, maar was 'n nuwe 'filantropiese' belangstelling in die sogenaamde 'natuurvolke' van hierdie nuutontdekte wêrelde wat nuwe lewe in die sending geblaas het. Besiel met die Franse Revolusie se idees van vryheid, gelykheid en broederskap, het sekere mense met die mens en sy regte begin dweep (Van der Vyfer 1958:397). Hierdie 'natuurvolke' van die onbekende lande, is as 'onskuldige natuurkinders, onbedorwe en sonder sonde' gesien. Humanitêre oorwegings wat hand aan hand met imperialistiese motiewe geloop het, het grootliks tot 'n nuwe belangstelling in die sending bygedra. Bosch (1991:304) stel dit onomwonde: 'Whether they liked it or not, the missionaries became pioneers of Western imperialistic expansion.' Dit is ook Spoelstra (1999:14) se oortuiging: 'Sending is in die klimaat van politieke verowering en verwestering ontplooi.'

Terwyl die kerk van die agtiende eeu nog slapend was, het die ontdekking van die nuwe wêrelde met filantropiese ywer die opkoms van verskillende sendinggenootskappe tot gevolg gehad. Wat die kerke nie gedoen het nie, sou die uitlandse genootskappe nou onderneem (Van der Vyfer 1958:397). Die sendingontwaking van die agtiende en negentiende eeu was buitekerklik en het gevolglik geen dogmatiese belyning gehad nie. Dit was die tyd van kerklike en leerstellige onbepaaldheid. Aanvanklik het hierdie sendingontwaking tot kragdadige aktiwiteite op die gebied van evangelisasie, sending en barmhartigheidsdiens gelei, maar dit het uiteindelik verflou veral omdat daar geen gefundeerde sendingteologie was nie (Du Plessis 1960:38). Van 'n kerklik-reformatoriese sendingsamewerking was daar teen die einde van die agtiende eeu geen sprake nie.

\section{Die teologiese ontwikkeling in Suid-Afrika}

Dit was wel die Gereformeerde godsdiens wat in 1652 aan die Kaap van Goeie Hoop sy ingang in hierdie onbekende wêreld gevind het. Die bande met die Gereformeerde Kerk in Nederland is gehandhaaf, en deur middel van die klassis Amsterdam onderhou. Die Kaapse Kerkraad was egter ook bewus van die feit dat hy die wil van die politieke owerheid in die Kaap moes uitvoer. Dit het die gevolg gehad dat die Kaapse kerkregtelike ontwikkeling nie langs gereformeerde bane verloop het nie (Spoelstra 1963:4). Die agtiende eeu met sy kreet van verdraagsaamheid, het 'een geest van diepe slaap in de jaren van 1816 tot 1830 over goed als geheel het kerkvolk' gekom 
(Van der Vyfer 1958:31-32). Die opkoms van die liberalisme in Suid-Afrika gedurende die negentiende eeu is direk toe te skrywe aan die rasionalistiese stromings wat gedurende die agtiende eeu in Europa plaasgevind het (Kruger 1957: 61).

Slegs 'n klein groepie Gereformeerde Nederlandse teoloë (die sogenaamde 'Oude Schrijvers') (D'Assonville soos aangehaal deur Kruger 1997:30-32) het aan die ou gereformeerde opvattings vasgehou en hulle gedagtes te boek gestel. Hierdie manne het onder die gereformeerde Piëtiste van die Nadere Reformasie getel (Malan \& Hofmeyer soos aangehaal deur Kruger 1997:30). Hulle het onwetend 'n beduidende invloed in Suid-Afrika uitgeoefen. Terwyl die Kaapse Kerk binne die vaarwaters van vrysinnige kerklike 'verandering' gestaan het soos dit vanuit Europa georkestreer is, was 'n groepie grensboere aan die Kaap grootliks van hierdie veranderings geïsoleer. Hulle het net met die Nederlandse Statevertaling en die boeke van die 'Oude Schrijvers' in die Kaapse binneland gewoon. Die geestelike atmosfeer wat in hierdie boerewonings geheers het, was volgens Jooste (1958:29) nog die gees van die Gereformeerde Nederland van die sewentiende en agtiende eeu. Hierdeur is dit volgens Spoelstra (1963:6) duidelik dat 'n baie hegte band tussen die sogenaamde 'Fijnes' van Nederland ('n skeldnaam vir die gereformeerde Piëtiste) en die Doppers ('n skeldnaam vir die ortodokse Gereformeerdes IWF; [outeur se invoeging]) in Suid-Afrika bestaan het.

Die veranderings wat in die Kaapse Kerk plaasgevind het, het toenemende spanning en beswaardheid van die kant van die 'Doppers' ontlok. Die Kaapse Kerk het homself uiteindelik volledig met die Genootskaplike sending vereenselwig en het vanweë hulle noue verbintenis met die staat en die politiek, 'n beleid van 'gelykstelling' in die Kaapse Kerk ingevoer. Dit het hierdie konserwatiewe gereformeerdes heeltemal dwars in die krop gesteek. Hierdie beswaardheid het uiteindelik op die afskeiding en stigting van die GKSA in 1859 uitgeloop (D'Assonville 1992:197-229; Spoelstra 1963:63-84, 112-168).

Die stigting van die Gereformeerde Kerk in Suid-Afrika op 11 Februarie 1859 het in 'n krisisuur vir die Christelike kerk in Suid-Afrika plaasgevind. Postma het dit in sy eie woorde gestel dat die Gereformeerde Kerk 'tegenover het hier diep gezonken Liberalisme, het ware Gereformeerde standpunt hernomen' (Van der Vyfer 1959:26). Hoewel die GKSA in 1859 totaal onafhanklik van enige kerklike gebeure in Nederland tot stand gekom het, is hulle tog volgens Spoelstra (1986:1) gedurende die eerste halfeeu vanuit die Christelike Gereformeerde Kerk in Nederland beïnvloed. Volgens Kruger (1997:34) het daar wel gedurende hierdie tyd 'n stuk Piëtisme die GKSA binnegesluip, aangesien die eerste predikante na 1859 feitlik almal uit hierdie kerk afkomstig was. Die Christelike Gereformeerde Kerk was die kerk van die Afskeiding van 1834, waarin die stroom van die Nadere Reformasie sy kontinuering gevind het. Gedurende die negentiende eeu het die Calvinisme in verskillende lande sterk opgeleef. Hierdie beweging is volgens Du Toit (1969:2) as NeoCalvinisme betitel, al was dit nie bedoel om ' $n$ afbuiging of verlating van die oorspronklike Calvinisme te wees nie. In Nederland het dit onder leiding gestaan van Abraham Kuyper. Spoelstra (1986:5) is daarvan oortuig dat die Rasionalisme van die agtiende eeu, tesame met Abraham Kuyper se filosofie van soewereiniteit in eie kring, asook die Wysbegeerte van die Wetsidee, die kerkbegrip onder hierdie neo-Calviniste in Nederland verwêrelds en vervlak het. Dit is juis hierdie 'nog sterker invloed' wat volgens hom, gedurende die tweede halfeeu van die Gereformeerde Kerke se bestaan, vanuit die Vrije Universiteit, die Doleansie en die Gereformeerde Kerke van Nederland (GKN), die GKSA beïnvloed het (Spoelstra 1986:1).

In die lig van hierdie uitspraak is dit daarom uiters belangrik om die Pluriformiteitsleer van Abraham Kuyper en die invloed daarvan op die GKSA, in oënskou te neem.

\section{Abraham Kuyper se Pluriformiteitsleer}

Abraham Kuyper het in die negentiende eeu na vore getree met ' $n$ herlewing van die Calvinisme (Velema 1989:57). Dit is 'n onbetwisbare feit dat hy met sy teologie 'n baie groot en wêreldwye invloed gehad het. Sy kerkbeskouing word gesien as die basis waarop die gereformeerde standpunt oor die getuienis van die kerk in die samelewing gefundeer is (Vorster 1996:180). Nie net is die hele Protestantse Nederland onder sy greep nie (Von Meyenfeldt soos aangehaal deur Buys 1970:10), maar sy ekklesiologie, en veral sy onderskeiding van instituutorganisme, het die GKN en ook tot 'n hoë mate die Gereformeerde Kerk in Suid-Afrika gestruktureer (Buys 1970:171; Vorster 1996:180).

Jonker (1989:12) huldig die ernstige mening dat Kuyper, onder andere deur sy visie op die kerk en veral deur sy pluriformiteitsleer, 'n handige instrument aan teoloë in Suid Afrika voorsien het waarmee hulle vanaf die veertigerjare die gedagte van aparte kerke vir aparte groepe, teologies probeer verantwoord het. Die laaste woord oor 'n moontlike ooreenkoms tussen die standpunte van Kuyper en die beleid van apartheid in Suid-Afrika is nog nie gespreek nie (Strauss 1993:323), aangesien daar in die SuidAfrikaanse gereformeerde kerklike konteks 'n duidelike 'appeal to Kuyperian theology to legitimate religiously the sovereignty of nations', gehoor word (Smit 1992:88). Smit (1992:89) kom tot die slotsom dat: 'the story of apartheid is thus part and parcel of the story of South African Reformed Theology'. Volgens Jonker (1989:22) sou dit baie maklik wees om die invloed van Kuyper aan te dui in die dokumente Ras, volk en nasie in die lig van die Skrif (NG Kerk 1977), asook die latere Kerk en Samelewing (NG Kerk 1986), ${ }^{6}$ en die reaksie daarop in Geloof en Protes (NG Kerk 1987). ${ }^{7}$

5. Hierdie boek kan besigtig word by https://www.abebooks.com/Ras-Volk-NasieVolkereverhoudinge-Lig-Skrif/15020445753/bd.

6.'n Skakel om hierdie boek te besigtig, is http://www.ngkerkas.co.za/wp-content/ uploads/KS.pdf.

7.Besoek vir hierdie boek https://books.google.co.za/books/about/Geloof_en_ protes. html?id=49buAAAACAAJ\&redir_esc=y. 
Wat is die pluriformiteit van die kerk? Die kerkgeskiedenis is 'n geskiedenis van verbroke eenheid (Durand 1961:44). Die eenheid en uniformiteit van die een kerk van Jesus Christus word met die jaartalle 1054 (die skeiding tussen die Rooms-Katolieke en die Grieks-Ortodokse kerk) en 1517 (Die Reformasie) 'n pluriformiteit, 'n kerklike verdeeldheid of verskeurdheid. Die kerk van Jesus Christus het nie meer in 'n eenheid gelewe nie, maar het in verskillende 'verskyningsvorms' verdeel.

Volgens Jonker (1989:14) sien Kuyper ware eenheid as die einddoel van al God se weë. Hierdie ware eenheid sal egter eers realiseer wanneer God uit die veelheid en verskeidenheid van die skepping en die geskiedenis, alle stryd sal verwyder in die komende koninkryk van die hemel. Hierdie eenheid wat God wil, sal dus eers met die voleinding van die tyd waarlik realiseer. Daar is egter nou 'n dringende gevaar wat dreig. Die sonde en die boosheid wil die mens daartoe verlei om alreeds hier op aarde te poog om die groot ideaal van hierdie eenheid te bereik. Hierdie moderne strewe na eenheid moet egter as 'n vloek beskou word, want dit is 'n soeke na 'n valse eenheid wat die werklikheid van die verskeidenheid wil dooddruk en dit as onbelangrik wil ignoreer. God het bedoel dat daar in sy skepping harmonie en vrede tussen al die verskeidenhede moet bestaan. Hierdie valse eenheidstrewe wat Kuyper dan ook met groot erns afwys, wil juis alle verskeidenheid wegneem en sodoende die vryheid vernietig (Jonker 1989:15). Met die erkenning van die pluriformiteit, word daar dus deur Kuyper ruimte gegee, sodat die verskeidenheid in sy eie plek geakkommodeer kan word.

Die gebruik van die term pluriformiteit is egter nie sonder enige probleme nie. Die term pluriformiteit is verwarrend, omdat dit poog om 'n té gekompliseerde verskynsel onder een noemer te bring (Durand 1961:52). Dit gaan nie maar net oor die feit van ' $n$ veelheid van kerke as gevolg van belydenisverskille nie, aangesien die veelvormigheid wat geëis word deur van plek, land, taal en volk te verskil, ook in berekening gebring moet word (Durand 1961:52).

Wat is die gevolge van Kuyper se leer vir die kerk? Die Pluriformiteitsleer van Kuyper het belangrike implikasies vir die kerk van Jesus Christus ingehou. Hiervolgens het hy op grond van sy onderskeiding tussen die sigbare en die onsigbare kerk, die sigbare kerk in twee bestaanswyses opgedeel, naamlik instituut en organisme. Die instituut is die amptelike organisasie van die gelowiges, die aardse sigbaarwording van die kerk wat in die hemel onsigbaar is (Kuyper soos aangehaal deur Vorster 1996:181). Die roeping van die kerk as instituut op aarde, is die diens van die Woord en alles wat met Woordbediening saamhang. Hier gaan dit oor die amptelike kerklike 'organisasie' waarbinne die ampte van predikant, ouderlinge en diaken funksioneer. Die kerk as organisme is daar waar die gelowiges in die samelewing betrokke is en elke dag leef en werk.

Hierdie beskouings van Kuyper het by uitstek die instituutmodel in die Gereformeerde Kerke gevestig. Dit het onder andere ook neerslag gevind in die Wysbegeerte van die Wetsidee nadat Dooyeweerd filosofies daarop voortgebou het. As gevolg van die 'soewereiniteit in eie kring' (Strauss 2019) is die kerk net maar nog 'n Christelike samelewingsinstelling of verband tussen ander 'Christelike samelewingsverbande'. Die kerk as instituut moet hom bepaal by dit wat die 'instituut' raak en nie inmeng op die terrein van die ander 'Christelike samelewingsverbande' nie. Dit beteken dat die kerstening van die samelewing, die Christelike lig op kuns, wetenskap en tegniek op die terrein van die organisme lê. Die instituut is net besig met die bediening van Woord en sakramente (Vorster 1996:182). Hiervolgens word die kerk as instituut se roeping vereng tot net dit wat die instituut raak. Die grootste deel van die roeping word na die organisme verplaas, sodat 'n groot deel van die kerklike 'las' op die skouers van die gelowiges in die samelewing rus. Die kerk word hiermee 'n doel op sigself en is alleen oor die voortbestaan van die instituut begaan. As gevolg hiervan het die roeping tot evangelisering in die Gereformeerde Kerke as gevolg van die instituutmodel oor die jare 'veramptelik' (Vorster 1996:131). Hierdie kerksentriese beskouing van die kerk verdring die koninkryk van God. Die gevolg is dat die kerk nie funksioneel in diens van die koninkryk van God is nie (Vorster 1996:192)

\section{Beoordeling van Kuyper se pluriformiteitsleer}

Kuyper het die organisme idee nie uit 'n gereformeerde bron ontvang nie (Buys 1970:175), maar is as kind van sy tyd deur die negentiende-eeuse organistiese denkbeeld beïnvloed (Buys 1970:179). Hy het dit ook te veel op die spits gedryf (Buys 1970:186). Kuyper het gepoog om 'n sintese te bewerkstellig tussen die ekklesiologiese beskouings van die Etiese ('spiritualiste-organisme') en die Konfessionele Rigtings ('institutionaliste-instituut') van sy tyd (Smit 1989:30). Kuyper se poging om hierdie uiteenlopende sienings van sy tyd met mekaar te versoen, asook die aanwesigheid van sekere nuanserings in die grondpatroon van sy onderskeiding, het tot veel verwarring by gereformeerde ekklesioloë ná hom, aanleiding gegee (Buys 1970:144). Velema spreek waardering uit vir Kuyper se goeie bedoelings en hy prys sy intensie, maar stel dit onomwonde dat Kuyper en sy teologie verlede tyd is (Velema 1989:60). Die resultate van Kuyper se organisasieaktiwiteite het omgeslaan na die teendeel van wat Kuyper beoog het (Velema 1989:59). Velema ag dit merkwaardig dat diegene wat Kuyper se erfgename moes wees, nou posisies inneem wat Kuyper juis bestry het (Velema 1989:57). Ook Jonker (1989:22) is daarvan oortuig dat Kuyper se motief nie dieselfde was as dié van die Suid-Afrikaanse teoloë wat hulle op hom beroep het nie. Uiteindelik moet Velema (1989:20) verklaar: 'Kuypers lewenstaak is bezweken onder het tweeschlachtige fundament.'

\section{Konklusie}

In Nederland, na die tyd van die Reformasie, het die opkoms van die ortodoksie nie net tot teologiese verstarring nie, maar ook tot dogmatiese verstarring gelei. Met hartseer moet 
erken word dat die Reformasie baie oppervlakkig in Nederland deurgewerk het. As gevolg van die feit dat daar geen verdere teologiese ontwikkeling in Nederland was nie, het die Piëtisme en Metodisme al hoe sterker gegroei. Dit was 'n reaksie teen die ortodoksie. Die beweging wat bekend is as die Nadere Reformasie het later uiting gevind in die sogenaamde neo-Calvinisme (Ferreira 2004). Die bekende Abraham Kuyper sou hier 'n baie belangrike rol speel en op hierdie manier ook 'n wesenlike invloed uitoefen. Sy 'kerksentriese visie' het wêreldwyd in reformatoriese kerke ingang gevind en het ongelukkig tot ekklesiologiese verstarring gelei. Vir sover dit die sendingfokus van die GKSA geraak het, het dit geen helderheid oor die roeping van die kerk in die wêreld gebring nie.

\section{Samevatting}

Die GKSA het die afgelope 25 jaar eers werklik bewus begin word van die realiteite van 'n post-Christendomse wêreld wat sigbaar en voelbaar besig is om al hoe duideliker te word. Dit is bloot die deurwerking van 'n proses van geestelike agteruitgang wat alreeds meer as 250 jaar besig is om in die Westerse wêreld plaas te vind. Terwyl sommige gereformeerdes nog verward wonder wat besig is om te gebeur en ander dalk nog in totale ontkenning lewe (Frost 2006:4), is die skrif duidelik aan die muur. Die feite is ook alreeds in die GKSA se sinode-rapporte opgeskryf. Terwyl die GKSA dankbaar terugkyk op 'n genade-geskiedenis van 150 jaar, kan die GKSA nie anders as om uiters 'ongemaklik' te wees, met waar sy haarself op hierdie oomblik bevind nie. As Gereformeerde Kerk moet ons altyd - en nou weer - dringend reformeer: Semper reformanda. Die volgende is duidelik en sal baie dringend aandag moet kry:

- Die gebrek aan 'n koninkryksvisie in die Gereformeerde kerklike teologie en bediening.

- Die gebrek aan 'n sendingfokus, asook die ongenoegsaamuitgewerkte sendingfokus van die Reformasie (Hestenes aangehaal deur Ogden 1990:7). ${ }^{8}$ Dit word baie duidelik sigbaar in die historiese en teologiese nalatenskap aan die GKSA vanuit Nederland.

Die optimisme deur Ogden uitgespreek, is nodig. Hy (Ogden 1990:11) is oortuig dat ons wat vandag lewe, deel is van die generasie wat die onafgehandelde werk van die Reformasie uiteindelik kan voltooi. Mag hierdie artikel daartoe bydra dat die GKSA, in die woorde van Bosch (1986:14), 'haar missionêre betrokkenheid in meer omvattende kategorieë sal sien, as wat ons in die verlede gewoond was om te doen'.

\section{Erkenning \\ Mededingende belange}

Die outeur verklaar dat daar geen finansiële of persoonlike verbintenis is met enige party wat hom nadelig kon beïnvloed in die skryf van hierdie artikel nie.

8.Dit kan ook beskrywe word as'n 'nog nie ontdekte', of eerder, 'n 'nog nie behoorlik wetenskaplik ontginde' sendingfokus van die Reformasie.

\section{Outeursbydrae}

I.W.F. was die enigste outeur betrokke by die skryf van die artikel.

\section{Etiese oorwegings}

Hierdie artikel volg alle etiese standaarde vir navorsing.

\section{Befondsingsinligting}

Hierdie navorsing het geen spesifieke toekenning ontvang van enige befondsingsagentskap in die openbare, kommersiële of nie-winsgewende sektore.

\section{Data beskikbaarheidsverklaring}

Die deel van data is nie van toepassing op hierdie artikel nie, aangesien geen nuwe data in hierdie studie geskep of ontleed is nie.

\section{Vrywaring}

Die sienings en menings wat in hierdie artikel uitgedruk word, is dié van die outeur en weerspieël nie noodwendig die amptelike beleid of posisie van enige geaffilieerde agentskap van die outeur nie.

\section{Literatuurverwysings}

Augustiny, W., 1963, Ga heen en verkondig: Twintig eeuwen christelijke zending, Zomer \& Keunings, Wageningen.

Bosch, D.J., 1986, 'Sending: 'n Prinsipiële besinning', In die Skriflig 20(79), 2-14.

Bosch, D.J., 1991, Transforming mission paradigm shifts in theology of mission, Mary-Knoll, New York, NY.

Bosch, D.J., 1997, Heil vir die wêreld, NG Kerkboekhandel, Pretoria.

Buys, P.J., s.a., The relevance of the mission theology and strategy of John Calvin for Africa today, Lesing, Mukhanyo Bybelkollege, KwaNdebele.

Buys, P.W., 1970, Die ekklesiologiese onderskeiding organisme en instituut as antwoord op die problematiek van die Volkskerk: 'n Historiese, prinsipiële en praktiese studie, ThD-proefskrif, Departement van Sendingwetenskap, PU vir CHO, Potchefstroom.

Coetzee, J.C., s.a., Klasdiktaat: Kanoniek Nuwe Testament, PU vir $\mathrm{CHO}$, Potchefstroom. D’Assonville, V.E., 1992, Gids vir kerkgeskiedenis, Marnix, Potchefstroom.

De Klerk, P.J.S., 1923, 'Kerk en sending in Suid-Afrika', ThD-proefskrif, Departement van Sendingwetenskap, Vrije Universiteit Amsterdam, Amsterdam.

Du Plessis, H., 1959, 'Die Gereformeerde Kerk en die sending', in S. Du Toit (red.), Die Gereformeerde Kerke in Suid-Afrika, Eeufeesgedenkboek 1859-1959, pp. 121-131, Die Kerkblad, Potchefstroom.

Du Plessis, H., 1960, Geskiedenis van die sendingwetenskap, Pro Rege, Potchefstroom.

Du Toit, S., 1969, 'Die koninkryk van God in die Ou Testament', in S. du Toit, T. van der Walt, W.J. Snyman \& S.C.W. Duvenage (red.), Die koninkryk van God, pp. 11-33, Potchefstroom Herald, Potchefstroom.

Du Toit, S., 1970, Handleiding vir die studie van die kerkgeskiedenis, Pro Rege, Potchefstroom.

Duignan, B. \& Cranston, M., 2020, 'Jean Jacques Rousseau', in A. Augustyn, P. Bauer, B. Duignan, A. Eldridge, E. Gregersen, A. McKenna et al. (eds.), Encyclopaedia Britannica, viewed 21 May 2020, from https://www.britannica.com/biography/ Britannica, viewed 21 Jean-Jacques-Rousseau.
Jay

Durand, J.J.F., 1961, 'Una sancta Catholica in sendingperspektief: 'n Analise van die probleme rondom kerklike pluriformiteit en ekumenisiteit in die sending', ThDproefskrif, Vrije Universiteit, Ten Have, Amsterdam.

Ferreira, I.W., 2002, 'Die kerk se sending in diens van God se koninkryk', M-verhandeling, Potchefstroom.

Ferreira, I.W., 2004, Die kerk en sending: In diens van God se koninkryk, Centre for Reformational Urban Ministry in Africa, besigtig 03 November 2019, vanaf http:// www.cruma.co.za/afrikaanse-artikels/die-kerk-en-sending-in-diens-van-god-sekoninkryk.

Floor, L., 1981, Die evangelie van die Koninkryk, NG Kerkboekhandel, Pretoria.

Floor, L., 1990, 'Die missionêre gemeente', in F. Denkema (red.), Evangeliseer!, pp. 94-100, NG Kerkboekhandel, Pretoria. 
Frost, M., 2006, Exiles: Living missionally in a post-Christian culture, Hendriksen, Peabody, MA.

Geloof en protes, 1987, 'n Antwoord namens beswaarde lidmate op sekere aspekte van 'kerk en samelewing', Die Voortsettingskomitee, Aurora Pers, Pretoria.

Gereformeerde Kerke in Suid-Afrika (GKSA), 1958, Handelinge van die drie-en-dertigste nasionale sinode te Potchefstroom, Administratiewe Buro, Potchefstroom.

Gereformeerde Kerke in Suid-Afrika (GKSA), 1961, Handelinge van die vier-en-dertigste nasionale sinode te Potchefstroom, Administratiewe Buro, Potchefstroom.

Gereformeerde Kerke in Suid-Afrika (GKSA), 1988, Handelinge van die drie en-veertigste nasionale sinode te Potchefstroom, Administratiewe Buro, Potchefstroom.

Gereformeerde Kerke in Suid-Afrika (GKSA), 1997, Handelinge van die ses-en-veertigste nasionale sinode te Potchefstroom, Administratiewe Buro, Potchefstroom.

Gereformeerde Kerke in Suid-Afrika (GKSA), 2015, Handelinge van die derde algemene sinode te Potchefstroom, Administratiewe Buro, Potchefstroom.

Gereformeerde Kerke in Suid-Afrika (GKSA), 2018, Handelinge van die vierde algemene sinode te Potchefstroom, Administratiewe Buro, Potchefstroom.

Godschalk, L.A.F., 1968, Het Koninkrijk Gods naar de Schriften, Uitgeverij De Vuurbraak, Groningen.

Grosheide, F.W., Den Hartogh, G.M., Honders, H.J., Van Itterzon, G.P., Nauta, D. (reds.), s.a., Geschiedenis der kerk, deel 2, Kok, Kampen.

Hamersma, T., 1911, De Geschiedenis van de Christelike kerk, Het Westen-Drukkerij, Potchefstroom.

Helberg, J.L., 1980, Die Here regeer: Openbaringslyn deur die Ou Testament, NG Kerkboekhandel, Pretoria.

James, F.A., 2001, 'The Calvin I never knew', in Reformed theological seminary casettes, Virtual Campus, Charlotte, NC

Jonker, W.D., 1989, 'Die pluriformiteitsleer van Abraham Kuyper', In die Skriflig 23(91), 12-23. https://doi.org/10.4102/ids.v23i91.832

Jooste, J.P., 1958, Die geskiedenis van die Gereformeerde Kerk in Suid-Afrika 18591959, Gereformeerde Kerke in Suid-Afrika, Potchefstroom.

Kane, J.H., 1978, A concise history of the Christian world mission: A panoramic view of missions from Pentecost to the present, Baker Book House, Grand Rapids, MI.

Kerk en Samelewing 1986, 'n Getuienis van die Ned Geref Kerk, Algemene sinodale kommissie, NG Sendingpers, Bloemfontein.

Kruger, B.R., 1957, Die ontstaan van die Gereformeerde Kerk in Suid-Afrika, V\&R Drukkery, Pretoria.

Kruger, J.J.F., 1997, Die universele koningsheerskappy van Christus en Gereformeerde Piëtisme, M-verhandeling, PU vir $\mathrm{CHO}$, Potchefstroom.

Kruger, M.A., 1990, 'Waarom "evangeliseer"?', in F. Denkema (red.), Evangeliseer!, pp. 189-199, NG Kerkboekhandel, Pretoria.

Lindijer, C.H., 1962, Kerk en koninkryk, Ten Have, Amsterdam.

Lindsay, T.M., 1908, A history of the reformation, vol. 2, Clark, Edinburgh.

NG Kerk, 1977, Ras, volk en nasie volkereverhoudinge in the Lig van die Skrif, NG KerkUitgewers, Kaapstad.
NG Kerk, 1986, Kerk en Samelewing, Algemene Sinodale Kommissie, Bloemfontein.

NG Kerk, 1987, Geloof en protes: ' $n$ antwoord namens beswaarde lidmate op sekere aspekte van Kerk en samelewing, Die Komitee, Bloemfontein.

Ogden, G., 1990, The new reformation: Returning the ministry to the people of God Zondervan, Grand Rapids, MI.

Schulze, L.F., 1978, Geloof deur die eeue, NG Kerkboekhandel, Pretoria.

Smit, C.J., 1989, 'Abraham Kuyper as kerkregkundige', In die Skriflig 23(4), 24-44. https://doi.org/10.4102/ids.v23i91.833

Smit, D.J., 1992, 'Reformed theology in South Africa: A story of many stories', Acto Theologica 12(1), 88-106.

Snyman, W.J., 1977, Nuwe en ou dinge: Uit die skat van die koninkryk, Pro Rege, Potchefstroom.

Spoelstra, B., 1963, Die 'Doppers' in Suid-Afrika 1760-1899, Nasionale Boekhandel, Kaapstad.

Spoelstra, B. 1986, 'Het ons kerk-wees in strukture gestol?', In die Skriflig 20(80) 4-16. https://doi.org/10.4102/ids.v20i80.1289

Spoelstra, B., 1999, Sending vir kerk of koninkryk, Potchefstroomse Teologiese Publikasies, Potchefstroom.

Strauss, P.J., 1993, 'Abraham Kuyper, ras en volk - en Suid-Afrika', In die Skriflig 27(3), 323-336. https://doi.org/10.4102/ids.v27i3.1464

Strauss, P.J. 2019, 'Wysbegeerte van die wetsidee', in Elektroniese Christelike Kernensiklopedie, besigtig 10 Desember 2010, vanaf http://cke.christians.co. za/2016/04/10/wysbegeerte-van-die-wets\%C2\%ADidee/.

Van Andel, H.A., 1912, De zendingsleer van Gisbertus Voetius, Kok, Kampen.

Van den Berg, J., 1956, Constrained by Jesus' love: An inquiry into the motives of the missionary awakening in Great Britian in the period between 1698 and 1815, Kok, Kampen.

Van der Vyfer, G.C.P., 1958, Professor Dirk Postma 1818-1890, Pro Rege, Potchefstroom.

Van der Vyfer, G.C.P. (red.), 1959, Die Gereformeerde Kerk in Suid-Afrika 1859-1959, Eeufeesgedenkboek, Die Kerkblad, Potchefstroom.

Van der Walt, T., s.a., Openbaringsgeskiedenis van die Nuwe Testament: ' $n$ Gids vir Bybelkunde-studente, Pro Rege, Potchefstroom.

Velema, W.H., 1989, 'Kuyper as theoloog: Een persoonlike evaluatie na dertig jaar', In die Skriflig 23(91), 56-73. https://doi.org/10.4102/ids.v23i91.835

Verkuyl, J., 1993, 'The biblical notion of kingdom', in C. van Engen, D.S. Gilliland \& P. Pearson (ed.), The good news of the kingdom, mission theology of the Third Millennium, pp. 71-81, Orbis Books, Mary Knoll, NY.

Vorster, J.M., 1996, Is die kerk funksioneel? Gedagtes oor Gereformeerde kerkvernuwing in ' $n$ post-moderne konteks, Potchefstroomse Teologiese Publikasies, Potchefstroom

Vriezen, Th.C., 1977, Hoofdlijnen der theologie van het Oude Testament, Veenema, Wageningen.

Warneck, G., 1902, Outline of a history of Protestant missions from the Reformation to the present time, in G. Robson \& H. Fleming (eds.), Revell Company, New York, NY.

Wiersinga, H.A., 1959, Geschiedenis van de zending, Kok, Kampen. 